\title{
Formulation and evaluation of mucoadhesive buccal patch of acyclovir utilizing inclusion phenomenon
}

\author{
Ankita Saxena, Gulab Tewari, Shubhini Awasthi Saraf* \\ Department of Pharmaceutics, Babu Banarasi Das National Institute of Technology and Management, Lucknow, India
}

\begin{abstract}
Mucoadhesive buccal patch releasing drug in the oral cavity at a predetermined rate may present distinct advantages over traditional dosage forms, such as tablets, gels and solutions. A buccal patch for systemic administration of acyclovir in the oral cavity was developed using polymers hydroxy propyl methyl cellulose (K4M), hydroxy propyl methyl cellulose (K15M), sodium carboxy methyl cellulose and poly vinyl pyrolidone (K30), plasticizer poly ethylene glycol (400) and a backing membrane of Eudragit (RL100). The films were evaluated in terms of swelling, residence time, mucoadhesion, release, and organoleptic properties. The optimized films showed lower release as compared to controlled drug delivery systems. Hence, an inclusion complex of acyclovir was prepared with hydrophilic polymer hydroxylpropyl beta-cyclodextrin in the molar ratio of 1:1. The inclusion complex was characterized by optical microscopy, FAB mass spectroscopy, and FTIR spectroscopy. Patches formulated with the acyclovir inclusion complex were evaluated along the same lines as those containing acyclovir alone. The in vitro release data revealed a substantial increase from $64.35 \%$ to $88.15 \%$ in the case of PS I and PS II batches, respectively, confirming the successful use of inclusion complexes for the formulation of buccal patch of acyclovir.
\end{abstract}

Uniterms: Buccal patches/drug release. Inclusion complexes/use. Acyclovir. Mucoadhesion.

\begin{abstract}
Mucoadesivos bucais liberadores de fármacos para a cavidade oral com taxa de liberação prédeterminada podem apresentar distintas vantagens em relação às formas farmacêuticas convencionais como comprimidos, géis e soluções. Neste trabalho, um adesivo bucal para administração sistêmica de aciclovir através da cavidade oral foi desenvolvido empregando-se os polímeros hidroxipropilmetil celulose (K4M), hidroxipropilmetil celulose (K15M), carboximetil celulose sódica e polivinil pirrolidona (K30), polietilenoglicol plastificado (400) e uma membrana suporte de Eudragit (RL100). Os filmes obtidos foram avaliados em termos de intumescimento, tempo de residência, mucoadesão, liberação e propriedades organolépticas. Os filmes otimizados apresentaram liberação mais lenta em comparação a outros sistemas de liberação controlada. Desta maneira, um complexo de inclusão de aciclovir foi preparado com o polímero hidrofílico hidroxipropil beta-ciclodextrina em proporções molares 1:1. O complexo de inclusão foi caracterizado por microscopia ótica, espectrometria de massas FAB e espectroscopia FTIR. Os adesivos formulados com o complexo de inclusão de aciclovir foram avaliados em paralelo com adesivos contendo aciclovir isolado. Os dados de liberação in vitro revelaram um aumento substancial, de $64,34 \%$ para $88,15 \%$, nos lotes PS I e PS II, respectivamente, confirmando o sucesso do uso de complexos de inclusão para a formulação de adesivos bucais de aciclovir.
\end{abstract}

Uniterms: Adesivos bucais/sistema de liberação. Complexos de inclusão/uso. Acyclovir. Mucoadesão.

\section{INTRODUCTION}

Buccal delivery of drugs provides an attractive alternative to the oral route of drug administration, par-

*Correspondence: Shubhini A Saraf. Department of Pharmaceutics, Babu Banarasi Das National Institute of Technology and Management, Sector-II, Dr. Akhilesh Das Nagar, Faizabad Road, Lucknow (U.P.) - India. E-mail: shubhini.saraf@gmail.com ticularly in overcoming the disadvantage associated with the latter. Problems such as first pass metabolism and drug degradation in the harsh gastrointestinal environment can be circumvented by administering drugs via the buccal route. Moreover, the oral cavity is easily accessible for self-medication and can be promptly terminated in case of toxicity by simply removing the dosage form from the buccal cavity. Buccal delivery also enables administerings 
drugs to patients who cannot be dosed orally via this route (Shojaei, 1998). Many mucoadhesive buccal films have been formulated to release drugs locally in order to treat for fungal infections in the oral cavity, such as oral candidiasis (Donnelly et al., 2007; Khanna et al., 1997; Rapka et al., 2003; Senel et al., 2000). Due to the versatility of the manufacturing processes, the release can be oriented either towards the buccal mucosa or towards the oral cavity (Morales, McConville, 2011). These dosage forms are usually prepared by casting a solution of the polymer, drug and any excipients (such as a plasticizer) on to a surface and allowing it to dry. Patches can be made $10-15 \mathrm{~cm}^{2}$ in size but are more frequently $1-3 \mathrm{~cm}^{2}$, and may present with an ellipsoid shape, so as to fit comfortably onto the centre of the buccal mucosa (Patel et al., 2011)

Acyclovir is the most effective antiviral drug against herpes simplex infection. The oral absorption of acyclovir is dose dependent and highly variable, with bioavailability ranging from $15-30 \%$. Percutaneous absorption of acyclovir is poor (Shojaei, 1998). The main drawbacks associated with this drug are gastric irritation, first pass metabolism and low oral bioavailability. Side effects associated with topical application of drug consist of stinging and burning sensation. However, on oral application, the drug is well tolerated. In case of intravenous administration, rashes, sweating and emesis are observed. Therefore, there is a need to formulate an oral delivery system for acyclovir that promotes systemic delivery, bypass of first pass metabolism and improved bioavailability.

Complexation with cyclodextrins has been reported to enhance the solubility, dissolution and bioavailability of poorly water-soluble drugs, once they are known to encapsulate drugs into their hydrophobic cavity without the formation of any bonds (Baboota, Agarwal, 2003; Fernandes et al., 2002).

The present study is aimed at formulating patches to act as transmucosal drug delivery systems containing the drug acyclovir and compare these with patches made with an inclusion complex of acyclovir, in order to improve oral bioavailability.

\section{MATERIAL AND METHODS}

Acyclovir was obtained as gift sample from Cipla Ltd. (Mumbai, India). Two different polymer grades of hydroxy propyl methyl cellulose, HPMC K4M and HPMCK15M, poly methacylic acid-co-methyl methacrylate(1:1) (Eudragit RL100) were obtained from Colorcon Asia Pvt. Ltd. (Goa, India) and Cadila Ltd. (Ahemdabad, India). Poly vinyl pyrolidone (PVPK30) and hydroxypropyl beta cyclodextrin (HPBCD) were obtained as gift samples from S.D.Fine-Chem Ltd. Mumbai, India and S.A. Pharma. Chem. Pvt. Limited (Mumbai, India). SCMC (sodium carboxymethyl cellulose) was obtained from Central Drug House (New Delhi, India).

\section{Preparation of patches}

The buccal patches were prepared using the solvent casting method. Three different polymers were used (HPMC K4M, HPMC K15M and SCMC), along with plastisizer (PEG 400) and a hydrophilic polymer (PVP $\mathrm{K} 30$ ), so that the patch could be made pliable. The quantity of different polymers was optimized as per details in Table I. The quantity of acyclovir was kept constant at 10 $\mathrm{mg}$. Weighed quantities of polymer, plasticizer and hydrophilic polymer were obtained. The drug and polymer were gradually added to $10 \mathrm{ml}$ of distilled water $\left(\right.$ at $90^{\circ} \mathrm{C}$ ), with constant stirring. The plasticizer and hydrophilic polymer were each added as per formula (Table I) after cooling the polymer solution to room temperature. This solution was then poured in glass Petri dishes $(3.9 \mathrm{~cm}$ radius and $1 \mathrm{~cm}$ height). The Petri dishes were stored in an incubator at $37{ }^{\circ} \mathrm{C}$ and patches were obtained by evaporation of solvent. The patches were then properly removed and cut in $10 \mathrm{~mm}$ diameter patches (Kashappa, Desai, 2004). A backing membrane, containing 2\% w/v of Eudragit RL 100 in acetone and plasticizer, was prepared according to the procedure described above and attached to each patch using adhesive (Table I).

\section{Evaluation of patches with acyclovir}

\section{Thickness uniformity of the patches}

Three patches of each formulation were set aside for measuring patch thickness using a micrometer screw gauge at three different places. The mean value was then recorded (Kashappa, Desai, 2004).

\section{Weight uniformity of the patches}

For evaluation of patch weight, three patches of each formulation were individually weighed on a digital balance (ATX 224, Shimadzu, Japan). Mean weight was then calculated for each formulation(Nafee, 2003).

\section{Surface $\mathrm{pH}$ of patches}

To determine surface $\mathrm{pH}$, three patches of each formulation were allowed to swell for two hours on the surface of an agar plate. Surface $\mathrm{pH}$ was measured by using $\mathrm{pH}$ paper placed on the surface of the swollen patch as per reported method (Patel and Poddar, 2009) (Table III). A mean of three readings was recorded. 
TABLE I - Formula for patches containing acyclovir

\begin{tabular}{|c|c|c|c|c|}
\hline Formulation & PVP K30 (mg) & PEG $400(\mathrm{ml})$ & Polymer concentration $(\mathrm{mg})$ & Drug (mg) \\
\hline \multicolumn{5}{|c|}{ SCMC (polymer) } \\
\hline PS0 & 0 & 0.16 & 400 & 10 \\
\hline PS1 & 4 & 0.16 & 400 & 10 \\
\hline PS2 & 8 & 0.16 & 400 & 10 \\
\hline PS3 & 12 & 0.16 & 400 & 10 \\
\hline \multicolumn{5}{|c|}{ HPMCK4M (polymer) } \\
\hline PH0 & 0 & 0.12 & 300 & 10 \\
\hline PH1 & 3 & 0.12 & 300 & 10 \\
\hline PH2 & 6 & 0.12 & 300 & 10 \\
\hline PH3 & 9 & 0.12 & 300 & 10 \\
\hline \multicolumn{5}{|c|}{ HPMCK15M (polymer) } \\
\hline PE0 & 0 & 0.08 & 200 & 10 \\
\hline PE1 & 2 & 0.08 & 200 & 10 \\
\hline PE2 & 4 & 0.08 & 200 & 10 \\
\hline PE3 & 6 & 0.08 & 200 & 10 \\
\hline
\end{tabular}

*SCMC indicates sodium carboxymethyl cellulose; HPMC, hydroxypropyl methylcellulose; PVP, polyvinylpyrrolidone; PEG, polyethylene glycol.

\section{Swelling index}

The swelling index was measured using the diameter method. The agar solution was prepared by dissolving $0.2 \mathrm{~g}$ of agar in $10 \mathrm{~mL}$ of warmed simulated saliva fluid, $\mathrm{pH} 6.8\left(50-70^{\circ} \mathrm{C}\right)$. This solution was then poured into a Petri dish and allowed to cool. After determining the initial patch diameter, each patch was allowed to swell on its respective surface of gel. The diameters of the patch were determined after 2, 5 and 7 hours, and results were recorded as the mean value of three readings. Swelling studies were performed for 7 hours because a residence time of 7 hours was recommended (Baboota, Dhaliwal, 2005) (Table IV).

The observations were recorded for three optimized formulations: PS1, PE1, PH2.

$$
\text { Swelling index }=\{(\text { Df-Di) } / \text { Di }\} \text { x 100, }
$$

where $\mathrm{Di}=$ initial patch diameter and $\mathrm{Df}=$ final patch diameter.

\section{Folding endurance}

Three patches of each formulation of bigger size, i.e., $2 \times 2 \mathrm{~cm}$, were cut using a sharp blade. Folding endurance was determined by repeatedly folding a small strip of patch at the same place until it ruptured. The number of times the patch could be folded at the same place without breaking resulted in the folding endurance value. The mean value was calculated and recorded (Alix, Ghania, 2003) (Table III).

\section{Ex-vivo mucoadhesive strength}

Mucoadhesive strength of the patch was measured using a modified two arm balance (Mario, Becirerics, 2004; Kashappa, Desai, 2004). Rabbit buccal mucosa used in the procedure was obtained from a local slaughterhouse and stored in simulated saliva fluid with a $\mathrm{pH}$ of 6.8 at $4{ }^{\circ} \mathrm{C}$. The experiment was performed within three hours of procurement of the mucosa. The patch was put onto the mucosa and preload $(50 \mathrm{~g})$ was added to establish bonding between the two, as per the reported method. The weight of water required to detach the patch from the buccal mucosa was noted. This was taken as a measure of mucoadhesive strength. The experiment was repeated with fresh mucosa in an identical manner for all the patches and the mean value of three readings was reported. Mucoadhesive strength $F$ $\left(\mathrm{kg} \mathrm{m}^{-1} \mathrm{~s}^{2}\right)$ is given by the following equation:

$$
\mathrm{F}=(\mathrm{Ww} \times \mathrm{g}) / \mathrm{A} \text {, }
$$

where $\mathrm{F}$ is the mucoadhesion force $\left(\mathrm{kg} \mathrm{m}^{-1} \mathrm{~s}^{2}\right), \mathrm{Ww}$ is the 
weight of added water, $\mathrm{g}$ is acceleration due to gravity $\left(\mathrm{cm} / \mathrm{s}^{2}\right)$, and $\mathrm{A}$ is the surface area of the patch $\left(\mathrm{cm}^{2}\right)$ (Table III).

\section{Drug content uniformity of the patches}

The drug content of patches was measured without the backing membrane. Hydrochloric acid $(0.008 \mathrm{~mL})$ was taken in a beaker and volume was brought to $10 \mathrm{~mL}$ with distilled water. The patch was dispersed in $5 \mathrm{~mL}$ of the solution above and volume was brought to $10 \mathrm{~mL}$ with pH 6.8 simulated saliva fluid. An analysis was conducted for $1 \mathrm{~mL}$ of this solution, in order to assess drug content by UV spectroscopy (UV1700, Shimadzu, Japan) at $250 \mathrm{~nm}$ (Bharti, 2007) (Table II).

\section{In vitro residence time}

In vitro residence time was determined using a locally modified USP disintegration apparatus (VTD-AV, Veego, India) (Bharti, 2007; Nafee, 2003). The disintegration medium used was $800 \mathrm{ml}$ of simulated saliva fluid, $\mathrm{pH} 6.8$, maintained at $37^{\circ} \mathrm{C}$. A segment of rabbit buccal mucosa, with $3 \mathrm{~cm}$ in length and $1 \mathrm{~cm}$ in width, was glued to the surface of a glass plate of similar dimensions, and vertically attached to the apparatus. The mucoadhesive patch was hydrated from one side with $2 \mathrm{~mL}$ of simulated saliva fluid, which consisted of a phosphated buffer saline with a $\mathrm{pH}$ of 6.8 and the hydrated surface was then brought in contact with the buccal mucosa. The whole assembly was allowed to move up and down so that the patch was completely immersed into the solution at its lowest position and washed out at its highest position. The time required for complete erosion or detachment of the patch from the mucosal surface was recorded (Table IV).

\section{In vitro membrane permeation studies}

Studies were carried out using porcine buccal mucosa obtained from a local slaughterhouse as a model membrane. The model membrane was found to be similar, in permeability, to the semi-permeable membrane. The in vitro permeation studies of acyclovir with the model membrane were performed using a modified Keshary Chien cell at $37 \pm 0.2{ }^{\circ} \mathrm{C}$ (Karlsmark et al., 2008). The temperature was maintained at $37 \pm 0.2^{\circ} \mathrm{C}$ by a water jacket surrounding the receiver chamber. The fresh buccal mucosa was kept in simulated saliva fluid until it was used for experimentation, to prevent dehydration of the membrane.
Freshly obtained buccal mucosa was mounted between the donor and receptor compartments. The patch was kept over the membrane and the two compartments were clamped together. The donor compartment was filled with $1 \mathrm{ml}$ of simulated saliva fluid, $\mathrm{pH} 6.8$, and the receptor compartment was filled with isotonic phosphate buffer, $\mathrm{pH}$ 7.4. Hydrodynamics in the receptor compartment was maintained by stirring with a magnetic bead at $100 \mathrm{rpm}$. Then, $1 \mathrm{ml}$ of the sample was withdrawn at predetermined time intervals (at 1 hour intervals for up to 7 hours) and analyzed for drug content by UV Spectroscopy at $250 \mathrm{~nm}$. This was replaced, each time, by $1 \mathrm{ml}$ of simulated saliva fluid, $\mathrm{pH} 6.8$, at $37^{\circ} \mathrm{C}$.

\section{Phase solubility studies}

In order to prepare patches containing the acyclovir inclusion complex, phase solubility studies were conducted to characterize the drug-to-polymer ratio in the inclusion complex (Pavankumar, Ramakrishna, 2005; Mario, Becirerics, 2004). The molar ratio of drug-to-polymer was optimized based on the solubility studies of acyclovir with different concentration of HPBCD. Solubility studies were carried out according to the method described by Higuchi and Connors (1965). An HPBCD solution was added, in different concentrations $\left(2^{-10} \times 10^{-3} \mathrm{M}\right)$, to the supersaturated solution of acyclovir, and then shaken at room temperature (for 36 hours). After reaching equilibrium, the solution was filtered and the concentration of acyclovir in filtrate was determined spectrophotometrically at $250 \mathrm{~nm}$, in reference to a suitably constructed standard curve. Also, slope and stability constant were calculated from the graph including concentration of acyclovir $\left(10^{-3} \mathrm{M} / \mathrm{mL}\right)$ versus concentration of HPBCD $\left(10^{-3} \mathrm{M} / \mathrm{mL}\right)$. The stability constant $\mathrm{K}$ is given by

$$
\mathrm{K}=\{(\text { slope } /(1-\text { slope }) \mathrm{S}\} \text {, }
$$

where $\mathrm{S}$ is the solubility of the drug in the absence of HPBCD.

\section{Preparation of inclusion complexes}

The inclusion complex was prepared using the common solvent method. The polymer HPBCD and acyclovir were taken, in a molar ratio of 1:1. The drug and polymer were dissolved in a sufficient volume of distilled water by stirring. The mixture was heated gently $\left(45^{\circ} \mathrm{C}\right)$ to obtain an inclusion complex of acyclovir. The inclusion complex was stored in an airtight container until further use (Vamshi et al., 2007). 


\section{Characterization of inclusion complexes}

Optical microscopy, Mass spectroscopy and FTIR spectroscopy were used for the characterization of inclusion complexes

Scanning electron microscopy was used to characterize the drug, polymer HPBCD and inclusion complexes, respectively (Philips 505 SEM, Holland.).

Mass spectroscopy was used to characterize the mass of the inclusion complex, in order to ascertain the proper preparation of inclusion complexes. Samples were each mounted on a clean metal tip of the FAB probe and then introduced into the spectrometer and characterized in a positive mode (FABMS, Jeol SX-102, Japan) (Baboota, Dhaliwal, 2005).

FTIR spectroscopy was used to characterize the drug, polymer and inclusion complex in terms of the presence of various functional groups (Patel, Poddar, 2009; Alix, Ghania 2003; Mario, Becirerics, 2004). IR spectrum was taken for the pure drug, for the pure polymer, and for the drug/ polymer physical mixture, at a wavelength ranging from $4000 \mathrm{~cm}^{-1}$ to $400 \mathrm{~cm}^{-1}$ (8400S FTIR, Shimadzu, Japan). The sample (solid substance) was ground with $\mathrm{KBr}$ in the ratio of 1:100 and was made into a disc after drying in a microwave at $160{ }^{\circ} \mathrm{C}$ and then pressed under high temperature and a pressure of 6 metric tons. All the spectra were compared for shifting of major functional peaks and also for the loss of functional peaks, if any, in order to study the interaction between drug and polymer (Upendra, Siddhartha, 2010).

\section{Preparation of patches with inclusion complexes}

The inclusion complex was incorporated into polymer solutions and the patches were prepared using the procedure described above and the formulae shown in Table II.

\section{Evaluation of patches with inclusion complexes}

Weight uniformity, thickness, swelling index, sur- face $\mathrm{pH}$, folding endurance, mucoadhesion force, drug content and residence time were measured by the methods described above. The values are shown in Table V. In vitro release studies were performed, as shown in Figure 4.

Scanning electron microscopy was performed for the optimized patch in both batches - the first containing the drug only and the second containing the inclusion complex - to evaluate the uniform distribution of the drug, as shown in Figure 5.

\section{RESULTS AND DISCUSSION}

Patches were prepared using acyclovir and an acyclovir inclusion complex, respectively, since the patches of the drug alone exhibited lower balance. The optimized formulations in the first batch were PS1, PE1 and PH2 and in the second batch they were PS11, PE11 and PH22. The thickness and weight, surface $\mathrm{pH}$, drug content, and folding endurance of the different formulations are shown in Tables III and V, for formulations without and with the inclusion complex, respectively.

Thickness was found to vary from 0.12 to $0.26 \mathrm{~mm}$. The weight of patches was found to vary from 0.0047 to $0.0086 \mathrm{~g}$. Folding endurance for patches SCMC, HPMC K4M and HPMC K15M was found to be in the order of $\mathrm{SCMC}>100$, HPMCK4M $>80$, and HPMC $\mathrm{K} 15 \mathrm{M}>70$, respectively. Surface $\mathrm{pH}$ was found to be in the range of 5.8 to 6.2 for all the formulations of the two batches. Surface $\mathrm{pH}$ for all formulations was well within range of salivary $\mathrm{pH}$ and would not cause irritation in the mouth. The swelling indices (Tables IV and V) for the first batch were found to be in the order of PS1 > PE1 > PH2, whereas, for the second batch, they were in the order of PS11 > PE11 > PH22.

The swelling index for the optimized formulations, i.e., PS11, PH22, and PE11, was found to be comparable to that of the first batch, i.e., PS1, PH2, and PE1. Mean drug content was found to vary between 0.49 and $0.56 \mathrm{mg}$ for the different formulations.

For the first batch, mean mucoadhesive strength for

TABLE II - Formulae for patches containing the inclusion complex of acyclovir

\begin{tabular}{lcccc}
\hline Formulation & PVP K30 $(\mathrm{mg})$ & PEG $400(\mathrm{~mL})$ & Polymer concentration $(\mathrm{mg})$ & Drug $(\mathrm{mg})$ \\
\hline $\begin{array}{l}\text { SCMC (polymer) } \\
\text { PS11 }\end{array}$ & 4 & 0.16 & 400 & 10 \\
\hline HPMC K4M (polymer) & 6 & 0.12 & 300 & 10 \\
PH22 & 2 & & & 10 \\
\hline HPMC K15 (polymer) & & 0.08 & 200 & 10 \\
PE11 & & & & \\
\hline
\end{tabular}


TABLE III - Characteristics of buccal mucoadhesive patches containing acyclovir

\begin{tabular}{lccccc}
\hline Formulation & Thickness $(\mathrm{mm})$ & Weight $(\mathrm{gm})$ & Surface $\mathrm{pH}$ & Drug content $(\mathrm{mg})$ & Folding endurance \\
\hline PS0 & $0.17 \pm 0.01$ & $0.0047 \pm 0.0021$ & 5.8 & 0.56 & 123 \\
PS1 & $0.25 \pm 0.04$ & $0.0073 \pm 0.0016$ & 5.7 & 0.52 & 132 \\
PS2 & $0.19 \pm 0.03$ & $0.0065 \pm 0.002$ & 5.6 & 0.49 & 127 \\
PS3 & $0.23 \pm 0.05$ & $0.0078 \pm 0.0016$ & 5.62 & 0.50 & 105 \\
PH0 & $0.12 \pm 0.04$ & $0.0086 \pm 0.0009$ & 5.65 & 0.52 & 93 \\
PH1 & $0.17 \pm 0.03$ & $0.0071 \pm 0.0019$ & 5.25 & 0.56 & 92 \\
PH2 & $0.22 \pm 0.05$ & $0.0059 \pm 0.0009$ & 6.2 & 0.52 & 87 \\
PH3 & $0.25 \pm 0.01$ & $0.0047 \pm 0.0046$ & 6.23 & 0.54 & 82 \\
PE0 & $0.27 \pm 0.03$ & $0.0050 \pm 0.0010$ & 6.03 & 0.55 & 73 \\
PE1 & $0.22 \pm 0.04$ & $0.0059 \pm 0.0009$ & 5.9 & 0.49 & 75 \\
PE2 & $0.20 \pm 0.02$ & $0.0040 \pm 0.0010$ & 5.83 & 0.52 & 71 \\
PE3 & $0.26 \pm 0.05$ & $0.0054 \pm 0.0013$ & 5.76 & 0.51 &
\end{tabular}

TABLE IV - Characteristics of buccal mucoadhesive patches containing acyclovir

\begin{tabular}{|c|c|c|c|c|c|}
\hline \multirow{2}{*}{ Formulation } & \multicolumn{3}{|c|}{ Swelling index $(\%)$} & \multirow{2}{*}{$\begin{array}{l}\text { Mucoadhesion force } \\
\left(\mathrm{N} / \mathrm{m}^{2}\right)\end{array}$} & \multirow{2}{*}{$\begin{array}{l}\text { Residence time } \\
\text { (hours) }\end{array}$} \\
\hline & 2 hours & 5 hours & 7 hours & & \\
\hline$\overline{\mathrm{PS} 1}$ & 40 & 67 & 72 & $5.8 \pm 0.23$ & $5.6 \pm 1.35$ \\
\hline PE1 & 23 & 36 & 66 & $6.3 \pm 0.27$ & $6.5 \pm 1.23$ \\
\hline PH2 & 16 & 30 & 60 & $5.3 \pm 0.35$ & $5.2 \pm 1.5$ \\
\hline
\end{tabular}

TABLE V - Characteristics of buccal mucoadhesive patches containing inclusion complexes

\begin{tabular}{lccc}
\hline Parameters & PS11 & PE11 & PH22 \\
\hline Thickness (mm) & $0.17 \pm 0.04$ & $0.15 \pm 0.03$ & $0.20 \pm 0.05$ \\
Weight (gm) & $0.0054 \pm 0.0013$ & $0.0048 \pm 0.0016$ & $0.0086 \pm 0.0009$ \\
Surface pH & $5.8 \pm 0.3$ & $6.02 \pm 0.4$ & $5.9 \pm 0.3$ \\
Folding endurance & 150 & 73 & 82 \\
Drug content (mg) & 0.56 & 0.53 & 0.54 \\
Swelling index (\%) & & & \\
After 2 hours & 39 & 16 & 20 \\
After 5 hours & 66 & 28 & 35 \\
After 7 hours & 70 & 58 & 62 \\
Mucoadhesion force $\left(\mathrm{N} / \mathrm{m}^{2}\right)$ & $5.8 \pm 0.201$ & $6.1 \pm 0.136$ & $5.5 \pm 0.323$ \\
Residence time (hours) & $5.6 \pm 0.208$ & $6.5 \pm 0.12$ & $5 \pm 0.35$ \\
\hline
\end{tabular}

optimized formulations PS1, PE1, and PH2 was found to be $5.8,6.2$, and $5.6 \mathrm{~N} / \mathrm{m}^{2}$, respectively, and mean mucoadhesive strength was found to be in the order of PE1 > PS1 > $\mathrm{PH} 2$. For the second batch, mean mucoadhesive strength of optimized formulations PS11, PE11, PH22 was found to be $5.8,6.1$, and $5.5 \mathrm{~N} / \mathrm{m}^{2}$, respectively, and was in the order of PE11 $>$ PS11 $>$ PH22. For the first batch, mean residence time for formulations PS1, PH2, and PE1 was found to be 5.6, 5, and 4.5 hours. For the second batch, mean residence time for the optimized formulations was found to be 5.6, 6.5 and 5 hours, respectively.

Drug release percentage was greater in formulation PS1, from the first batch, and in formulation PS11, from the second batch. The release of acyclovir from HPMC patches 
TABLE VI - Release profile from the optimized formulations with and without the inclusion complex

\begin{tabular}{ccccccc}
\hline \multicolumn{7}{c}{ Cumulative percent drug release from optimized formulations } \\
\hline Time (hours) & PS1 $^{\#}$ & PS11* & PH2 & PH22* & PE1 $^{\#}$ & PE11* $^{*}$ \\
\hline 1 & 14.32 & 3.16 & 6.23 & 3.92 & 7.1 & 3.57 \\
2 & 35.06 & 9.41 & 7.45 & 10.29 & 10.05 & 12.75 \\
3 & 39.06 & 17.02 & 15.15 & 17.31 & 15.23 & 20.31 \\
4 & 42.35 & 28.64 & 20.69 & 25.68 & 25.37 & 32.78 \\
5 & 48.15 & 45.56 & 23.32 & 34.90 & 35.11 & 42.56 \\
6 & 59.23 & 65.35 & 28.15 & 44.65 & 40.13 & 51.31 \\
7 & 64.35 & 88.15 & 33.73 & 55.53 & 43.57 & 62.34 \\
\hline
\end{tabular}

* with inclusion complex; ${ }^{\#}$ without inclusion complex

was slower when compared to that of SCMC patches. In the first batch, the cumulative release percentage from the optimized formulations $\mathrm{PH} 2$ and PE1, respectively, was $33.73 \%$ and $43.57 \%$ in 7 hours, whereas the cumulative release percentage from SCMC (PS1) was $64.35 \%$. This was attributed to low aqueous solubility of polymers HPMC K4M and HPMC K15M. Out of the two sustaining polymers, HPMC K15M showed higher drug release due to higher swelling, when compared to HPMC K4M. The release profile from optimized formulation PS11 containing the inclusion complex was $88.15 \%$, which was much higher than the value for formulation PS1 (64.35\%). With regard to the second batch, formulations PE11 and PH22 with inclusion complexes released $62.34 \%$ and $55.53 \%$ of the drug, respectively, whereas formulations $\mathrm{PE} 1$ and $\mathrm{PH} 2$ with the drug alone released $43.57 \%$ and $33.73 \%$ of the drug, respectively, in a time interval of 7 hours. (Table VI)

Swelling controlled release system is given by equation

$$
\mathrm{M}_{\mathrm{T}} / \mathrm{M}_{\infty}=\mathrm{Kt}^{\mathrm{n}} \text {, }
$$

where $\mathrm{Mt} / \mathrm{M} \infty$ = fraction of drug released, $\mathrm{T}=$ release time, $\mathrm{K}=$ constant incorporating structural and geometrical characteristics of controlled system, and $n=$ release exponent.

When $\mathrm{n}<0.5$, release is said to be Fickian, controlled by the diffusion of the drug, and when $\mathrm{n}=0.5-1$, release is said to be non-Fickian. Here, the value of $n$ for all the formulations was found to be between 0.5 and 1 , suggesting that the drug follows non-Fickian release and is released by both erosion and diffusion mechanisms.

SCMC is a hydrophilic polymer, which swelled during dissolution, forming a gel layer. The loosely bound polymer molecules were easily eroded, allowing release of acyclovir at a faster rate, when compared to other cellulosic derivatives. The inclusion complex further enhanced drug release by incorporating the drug in its cavity and preventing direct contact of water-insoluble drug with the medium. From the release studies, it was found that the drug followed zero-order release kinetics. Phase solubility studies were performed to characterize the ratio of polymer-to-drug. Since the slope of the diagram was less than 1 (0.0001), the complex stoichiometry was observed to be $1: 1$. Value of the stability constant was found to be 11.98. A linear increase in the solubility of acyclovir was observed with increased concentration of HPBCD.

Therefore, the molar ratio of drug-to-HPBCD was taken to be 1:1. SEM analysis showed that the drug was crystalline in nature and that crystals were transparent. The polymer was found to be amorphous in nature. The inclusion complex was found to be crystalline in nature, having translucent crystals showing an association between the drug acyclovir and the polymer HPBCD (Figure 1).

Mass spectroscopy was used as a technique to confirm the formation of inclusion complex of acyclovir in a 1:1 molar ratio with HPBCD. The mass spectrum of the pure drug, polymer HPBCD, and the inclusion complex was taken and analyzed for molecular ion peak. It was found that polymer, drug and inclusion complex showed peaks at their respective molecular mass (Figure 2).

FTIR spectrum of acyclovir polymer and inclusion complex showed the presence of peaks: N-H stretching vibrations at $3301 \mathrm{~cm}^{-1}, 3442 \mathrm{~cm}^{-1}$, N-H bending vibrations at $1585.38 \mathrm{~cm}^{-1}, 1610.45 \mathrm{~cm}^{-1}, \mathrm{C}-\mathrm{N}$ stretching of primary amines at $1309.56 \mathrm{~cm}^{-1}$, and aromatic nucleus in the drug at $781.12 \mathrm{~cm}^{-1}$. Polymer HPBCD showed peaks at C-H stretching $\left(2927.74 \mathrm{~cm}^{-1}, 1157.21 \mathrm{~cm}^{-1}\right)$, aromatic nucleus $\left(657.66 \mathrm{~cm}^{-1}, 705.90 \mathrm{~cm}^{-1}, 756.04 \mathrm{~cm}^{-1}\right), \mathrm{O}-\mathrm{H}$ stretching $\left(3479.34 \mathrm{~cm}^{-1}\right)$. The inclusion complex IR spectrum showed disappearance of $\mathrm{O}-\mathrm{H}$ stretching and $\mathrm{N}-\mathrm{H}$ stretching peaks, indicating interaction between the hydroxyl group of the polymer HPBCD and the drug acyclovir (Figure 3). 


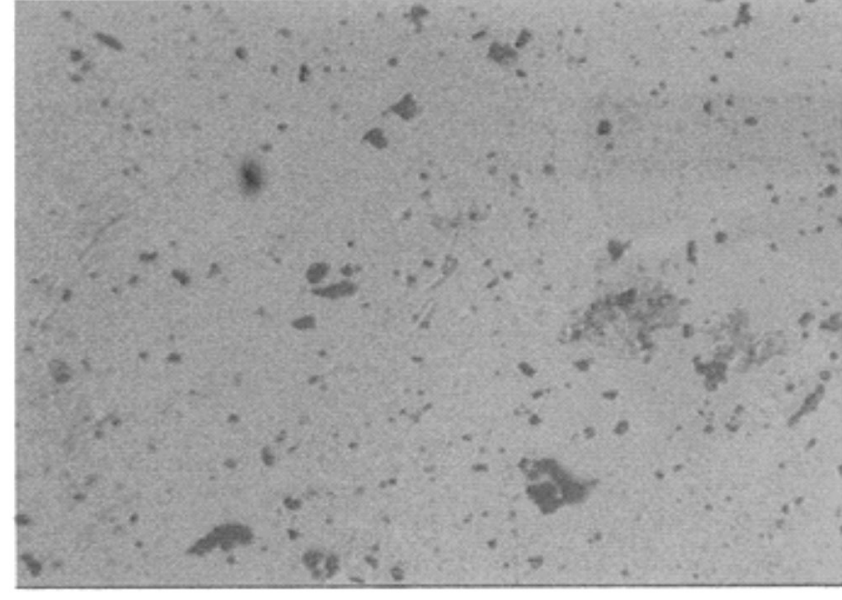

(a)

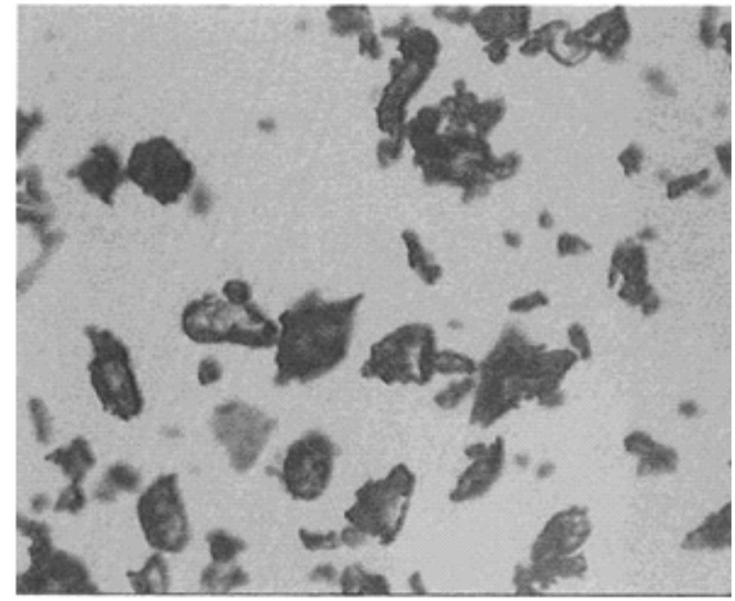

(b)

FIGURE 1 - SEM Photo micrographs of (a) acyclovir, and (b) acyclovir inclusion complex.

(a)
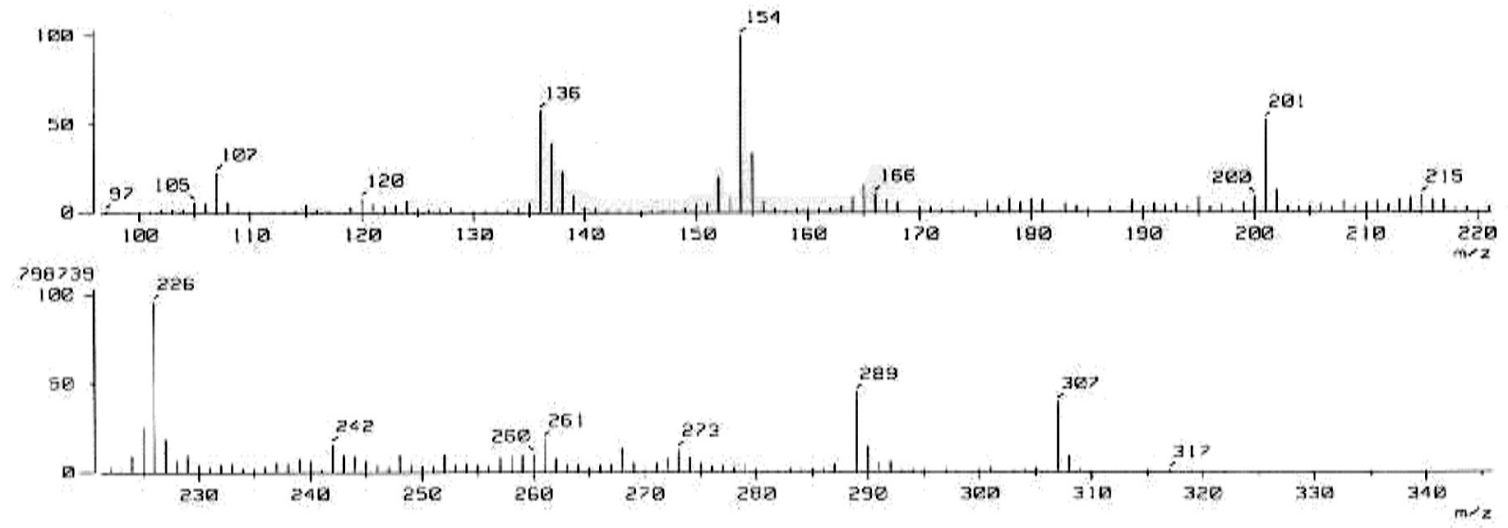

(b)
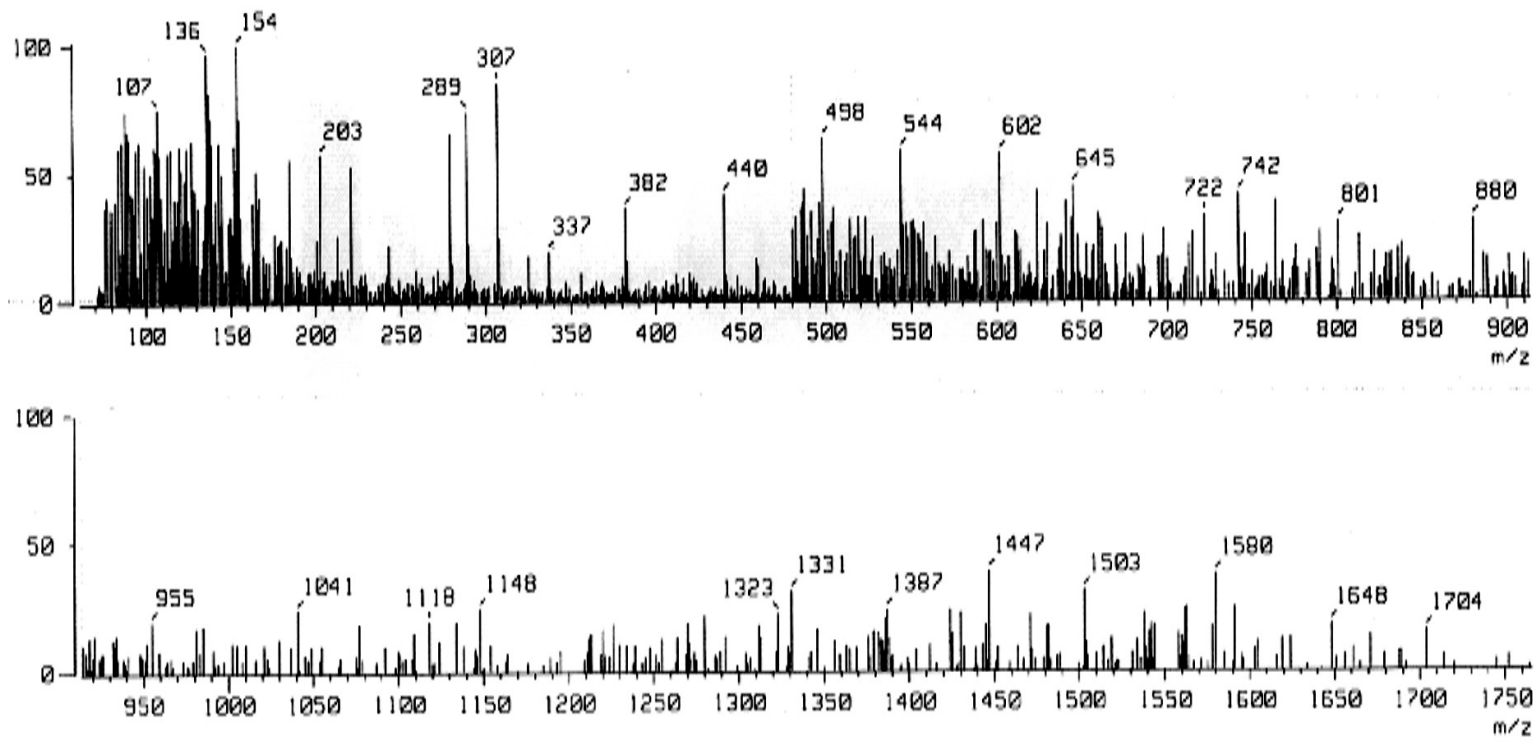

FIGURE 2 - Mass spectrum of (a) acyclovir, and (b) inclusion complex. 


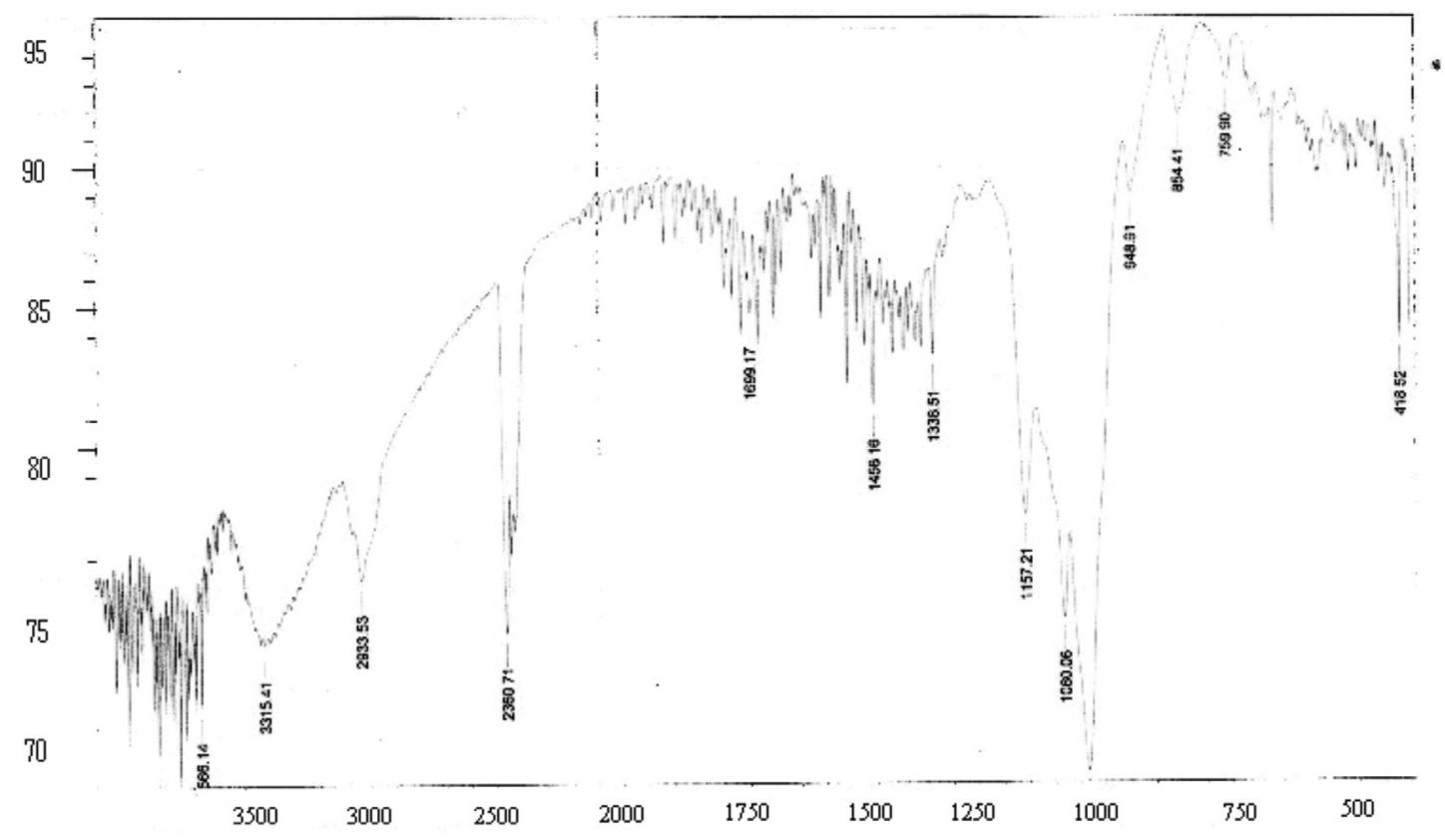

FIGURE 3 - Fourier transform infrared spectrum of inclusion complex.

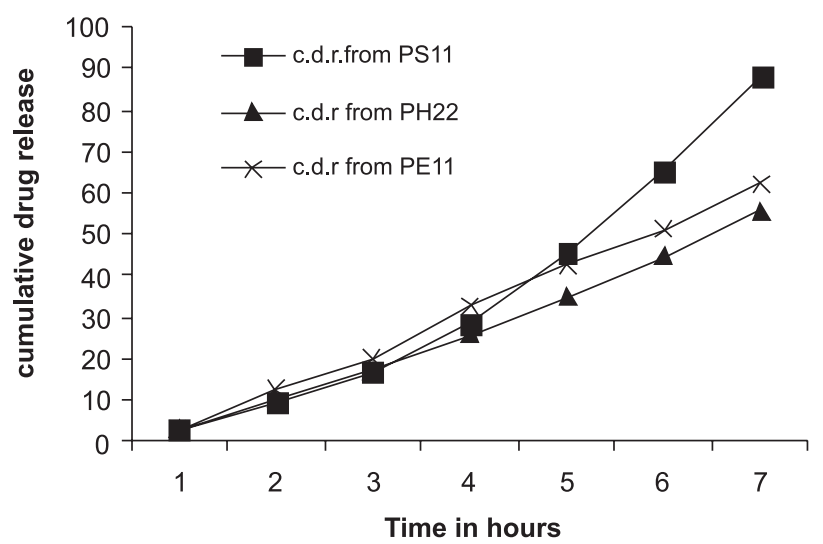

FIGURE 4 - Release profile of acyclovir from patches with inclusion complex.

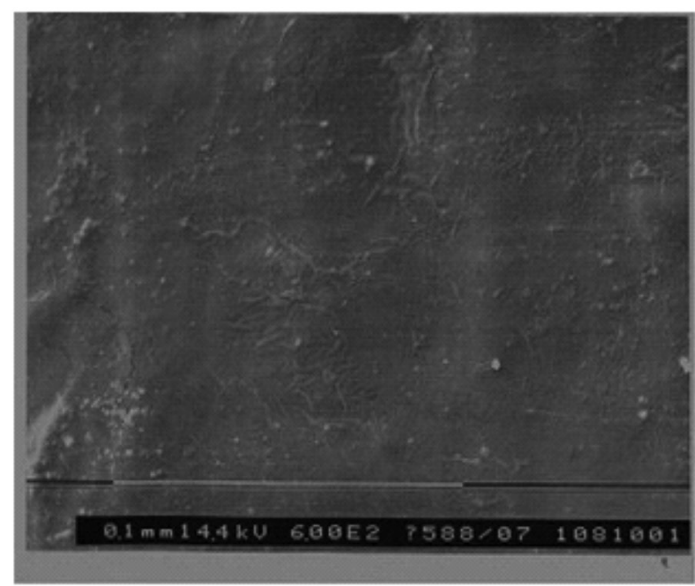

(a)
A substantial increase in the cumulative release percentage of acyclovir was observed in the case of patches containing inclusion complex (Table VI and Figure 4), which was approximately $20 \%$ in each case, i.e., PS I and PS II, PH2 and PH22, and PEI and PEII, respectively. This could be attributed to the increased solubility of drug with the use of the HPBCD inclusion complex.

The patches were analyzed for uniform distribution of the drug in the optimized formulations PS1 and PS11 by scanning electron microscopy. It was found that the drug was more uniformly suspended in the patch containing the drug alone (Figure 5), in comparison with the patch containing the drug polymer inclusion complex. However, the benefit of increased

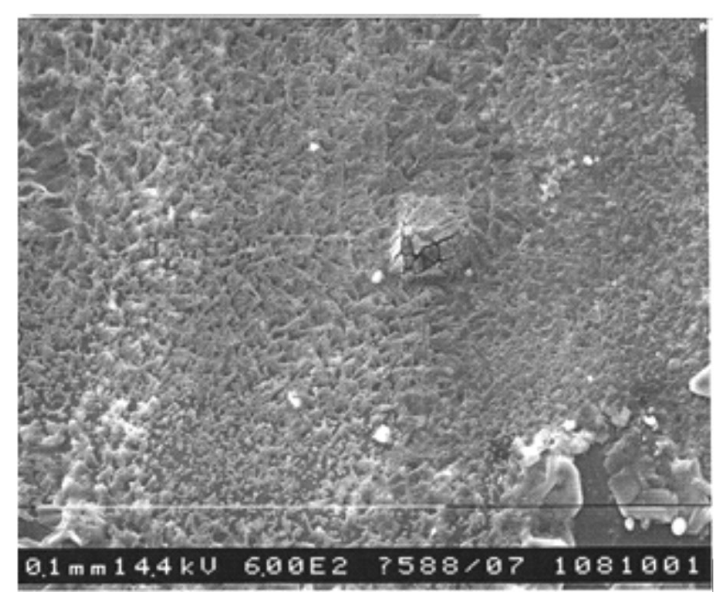

(b)

FIGURE 5 - SEM of patches containing (a) acyclovir, and (b) acyclovir inclusion complex. 
bioavailability outweighed this anomaly in physical parameters.

\section{CONCLUSION}

The incorporation of acyclovir inclusion complex into buccal patches was able to substantially enhance the percentage of drug released from the patches, thereby increasing bioavailability. Transmucosal buccal delivery of acyclovir could be developed as a potential method for the treatment of herpes simplex infections.

\section{REFERENCES}

ALIX, D.; GHANIA, D. Synthesis and characterization of sulphated $\alpha, \beta$ and $\gamma$ cyclodextrins : application to the complexation of Acyclovir. Carbohydr. Res., v.38, n.21, p.2185-2193, 2003.

BABOOTA, S.; AGARWAL, S.P. Refecoxib complexation with CD: Influence on the anti-inflammatory and ulcerogenic activity. Pharmazie, v.58, n.1, p.73-74, 2003.

BABOOTA, S.; DHALIWAL, M. Physiochemical characterization, in vitro dissolution behaviour and pharmacodynamic studies of refecoxib-cyclodextrin inclusion complex. preparation and properties of refecoxibhydroxypropylbetacyclodextrin inclusion complex. AAPS Pharm. Sci., v.6, n.1, p.E83-E90, 2005.

BHARTI, S. N. Improved dissolution of Valdecoxib inclusion complex with hydroxypropylbetacyclodextrin. AAAPS Pharm. Sci. Tech., v.69, n.3, p.442-445, 2007.

DONNELLY, R.; MCCARRON, P.; TUNNEY, M.; WOOLFSON, A. Potential of photodynamic therapy in treatment of fungal infections of the mouth. Design and characterisation of a mucoadhesive patch containing toluidine blue O. J. Photochem. Photobiol. B: Biol., v.86, n.1. p. 59-69, 2007.

FERNANDES, C. M.; VIERA, M. T.; VEIGA, F.J.B. Physicochemical Characterization and in vitro dissolution behaviour of nicardipine-cyclodextrin inclusion compounds. Eur. J. Pharm. Sci., v.15, n.1, p.79-88, 2002.
HEARNDEN, V.; SANKAR, V.; HULL, K.; JURAS, D.V.; GREENBERG, M.; KERR, A.R.; LOCKHART, P.B.; PATTON, L.L.; PORTER, S.; THORNHILL, M.H. New developments and opportunities in oral mucosal drug delivery for local and systemic disease. Adv Drug Deliv. Rev., doi:10.1016/j.addr.2011.02.008.

HIGUCHI, T.; CONNORS, K. A. Advances in analytical chemistry instrumentation. New York: Wiley Interscience, 1965. v. IV. p.117-212

KARLSMARK, T.; GOODMAN J.J.; DROUAULT, Y.; LUFRANO, L.; PLEDGER, G.W. Randomized clinical study comparing compeed cold sore patch to Acyclovir cream $5 \%$ in the treatment of herpes simplex labialis. J. Eur. Acad. Dermatol. Venereol., v.22, n.10, p.1184-1192, 2008.

KASHAPPA, G.; DESAI H. Preparation and evaluation of novel buccal adhesive system. AAPS Pharm. Sci. Tech., v.5, n.3, p.1-9, 2004.

KHANNA, R.; AGARWAL, S.P.; AHUJA, A. Preparation and evaluation of muco-adhesive buccal films of clotrimazole for oral candida infections. Indian J. Pharm. Sci., v.59, p.299-305, 1997.

MARIO,J.; BECIRER I C S, L. Influence of hydroxypropylbetacyclodextrin complexation on Piroxicam release from buccoadhesive tablet. Eur. J. Pharm., v.21, n.2-3, p.251-260, 2004.

MORALES, J.O.; McCONVILLE, J.T. Manufacture and characterization of mucoadhesive buccal films. Eur. J. Pharm. Biopharm., v.77, n.2, p.187-199, 2011.

NAFEE, N.A. Design and characterization of mucoadhesive buccal patch containing Cetylpyridinium chloride. Acta Pharm., v.53, n.3, p.199-212, 2003.

PATEL, S.R.; PODDAR, S.S. Development and Characterization of Mucoadhesive Buccal Patches of Salbutamol Sulphate. Curr. Drug Deliv., v.6, n.1, p.140-144, 2009.

PAVANKUMAR, G.V.; RAMAKRISHNA, V.; WILLIAM, J.; KONDE, A. Formulation and evaluation of buccal films of Salbutamol sulphate. Indian. J. Pharm. Sci, v.67, n.2, p.160-164, 2005. 
REPKA, M.; PRODDUTURI, S.; STODGHILL, S. Production and characterization of hot-melt extruded films containing clotrimazole. Drug Dev. Ind. Pharm., v.29, n.7, p.757-765, 2003.

SENEL, S.; IKINCI, G.; KAS, S.; YOUSEFI-RAD, A.; SARGON, M.; HINCAl, A. Chitosan films and hydrogels of chlorhexidine gluconate for oral mucosal delivery. Int. J. Pharm., v.193, n.2. p.197-203, 2000.

SHOJAEI, H.A. Transbuccal delivery of Acyclovir (II): Feasibility, System design and In vitro Permeation Studies. J. Pharm. Pharm. Sci, v.1, n.2, p.66-73, 1998.
UPENDRA, K.; SIDDHARTHA, D. Design and development of Felodipine buccal mucoadhesive patches. Int. J. Curr. Pharm. Res., v.2, n.3, p.72-75, 2010.

VAMSHI, V.Y.; CHANDRASEKHAR, K.; RAMESH, G. MADHUSUDHANRAO, Y. Development of mucoadhesive patches for buccal administration of Carvedilol. Curr. Drug Deliv., v.4, n.1, p.27-39, 2007.

Received for publication on $12^{\text {th }}$ April 2011 Accepted for publication on $10^{\text {th }}$ October 2011 
